\title{
1. The state and the civil society in the scholarship of higher education
}

\author{
Brian Pusser
}

Historically, the state, particularly the federal government, has been seen as either the font of higher education funding, whether for science or system expansion, or as an intrusive force, interfering with the development of professional and scientific expertise and constraining the free market of faculty. Although these are indeed characteristics of government action, scholars have begun to recognize that the state is intertwined with and perhaps inseparable from postsecondary education. (Slaughter, 1990, p. 1)

\section{INTRODUCTION}

A quarter-century has passed since Sheila Slaughter pointed to the need to understand the ways in which a state-theoretical approach could help scholars and researchers better understand political action in higher education. However, since Slaughter's (1990) analysis of the contest between the state and market forces in shaping postsecondary education in The Higher Learning and High Technology, relatively few scholars have built upon her observation that the university is an institution nested in the broader state, and subject to the political contest between the state, the civil society, and the institutions themselves. Instead, the evolution in the scholarly literature on the politics of higher education has been toward a functionalist, rational-choice vision of the politics of higher education, one increasingly shaped by neoliberal understandings of policy and practice (Friedman and Friedman, 1980).

Explaining this dearth of state-centered scholarship entails understanding not only the ways in which the discipline of higher education has incorporated political science into the field, but also the ways in which higher education has been treated in such key disciplines as sociology, philosophy, economics, and critical studies (Pusser et al., 2012). A state-theoretical model offers a holistic approach to the politics of higher education, one that acknowledges the role of government as well as other institutions, including the legal and executive branches of the state, regulatory entities, institutions of national security, and more. The state-centered approach also turns attention to contest between the state and civil society writ large, as well as contest driven by such elements of the civil society as political parties, unions, religious institutions, market forces, foundations, and other forms of non-governmental agencies. Assessing the state in contest also calls for acknowledging forces marginalized by both the state and civil society, those disenfranchised individuals and groups that arise as social movements that may powerfully influence actions by the state, the government, and the civil society.

In the United States, the dearth of critical approaches to the politics of higher education, and in particular the quite limited application of state theory until nearly the dawn of the twenty-first century, is attributable to the discipline's belated embrace of critical 
approaches and to a dearth of models attempting to conceptualize universities as political institutions of the state (Ordorika and Lloyd, 2015; Pusser, 2004; Slaughter and Leslie, 1997). In the field of higher education, the slow evolution of a politics of universities has been shaped by the long domination of conceptual models for understanding universities that focused on postsecondary institutions as organizations guided by institutional, rather than political, theories. That work drew largely from traditional models in sociology (Baldridge, 1971; Clark, 1983; Trow, 1976). It also relied on interest group-centered conceptions of the university and its leaders as autonomous "interest articulators" (Baldridge, 1971; Berdahl, 1971, 1990; Kerr, 1963).

Burton Clark's triangle of authority relations, which proposed that the governance of higher education institutions in various national contexts could be understood by the strength of the state, market forces, or an "institutional oligarchy" of academic regulatory authority, was an early and influential model for understanding the state and higher education (Clark, 1983). Clark's work located postsecondary institutions, and attributed some of their structures and practices to dominant interests within their respective states. He placed the United States closest to market influence, the USSR and Sweden nearest the authority of the state itself, and Italy and Britain under the sway of the academic oligarchy. In essence, Clark argued that different states produced higher education systems with distinct structures and approaches to postsecondary organization and governance. Early state-centered research in higher education was also provided by Cynthia Hardy (1990), Sheila Slaughter (1990), Clyde Barrow (1990), and Gary Rhoades (1992), scholars who brought the concepts of ideology, hegemony, and power to the study of state provision and oversight of higher education. These works complemented Clark's as they sought to more deeply explicate the relationship between state ideology and the provision of higher education in a given context. Rhoades (1992) noted the dearth of scholarship that relied on state-theoretical models, or that conceptualized a relationship between higher education and the state, summing up the literature in the field this way: "The state is distinct from, and in contraposition to, the academy" (p. 85).

The purpose of this chapter is to provide context from the study of the state and the civil society in the social sciences more broadly, in order to present a model for the ways in which the politics of postsecondary education might be better understood through the application of theories of the state and the civil society.

\section{UNDERSTANDING THE STATE}

Michael Mann (1988) has argued that definitions of the state often entail two perspectives: an institutional perspective that focuses on the structure of the state, and a functional perspective that concentrates on state action. He noted that institutional perspectives have been more prominent, as embodied in what he saw as a modified Weberian definition of the state that focuses on four elements:

1) A differentiated set of institutions and personnel embodying 2) centrality in the sense that political relations radiate outwards from a centre to cover 3) a territorially demarcated area, over which it exercises 4) a monopoly of authoritative binding rule-making, backed up by a monopoly on the means of physical violence. (Mann, 1988, p.4) 
The state is defined here as "encompassing political institutions, laws, rules and regulations, judicial systems, and formal systems of power including law enforcement and military organizations, as well as a variety of other formal organizations that serve to shape collective activity and protect individual rights" (Pusser and Marginson, 2012, p. 92). Those broad constructs cannot do justice to the myriad historical and contemporary understandings of the state, its structures and its activities, but they serve as a useful starting point.

The state has also been analyzed in a variety of ways in different intellectual disciplines, philosophies, ideologies, and traditions. Some of the earliest approaches to the organization of political society came from Plato's writings on the ancient city-state. Hay and Lister (2006) traced the evolution of the concept through Machiavelli's vision of the state as a defined territory (both geographical and political) with institutions of governance presided over by a monarch, to Renaissance republics with both civil and political authority shaping a state with a monopoly on the legitimate use of force and authority, one where the actions of the state derive legitimacy from the people. They suggested these developments led to the "absolutist" state described by Hobbes, in which the state is seen as "truly separate from the powers of the rulers and the ruled" (Hay and Lister, 2006 , p. 7). By the latter portion of the eighteenth century, distinct schools of thought on social, political, and economic organization emerged, perhaps most notably Adam Smith's argument for individual self-interest, as expressed through economic transactions and market relations as the most effective way to bind societies and shape both state and civil society (Smith, 1776 [1979]).

In the early nineteenth century Hegel conceptualized the state as the dominant social and political organization, one that combined individual sovereignty with social integration, and differentiated the state and civil society. This view and similar subsequent analyses of the state and civil society were challenged by Marx, who argued that both the state and the civil society were subordinate to the relations of economic production (Chandhoke, 1995). In a further important strand of state theorization at the turn of the twentieth century, Max Weber (1947) linked the formalization of the state to the institutionalization of an administrative elite that would provide and enforce rules designed to preserve the legitimacy of state action, particularly the use of coercive force. Weber's formalization of the state, and the importance he placed on culture and the institutions of the civil society in shaping state action, opened critical space for subsequent work on the state.

One of the most prominent advances in the scholarship of the state was developed by Antonio Gramsci (1971), who emphasized the state as a site of contest, with forces well beyond the formations of capital and labor vying for hegemony. Gramsci added other elements to the focus on class relations in Marxist thought, as he argued that political contest encompasses struggles that are not limited to economic relations (Simon, 1982). His work turned particular attention to the importance of the civil society, the role of ideology, culture, and agency, and the development and transformation of political consciousness based in lived experiences, as key elements of hegemonic struggle. As Gramsci wrote, "What we can do, for the moment, is to fix two major superstructural 'levels': the one that can be called 'civil society', and that is, the ensemble of organisms commonly called 'private', and that of 'political society', or 'the state"' (Gramsci, in Simon, 1982, p. 68).

The link between the state, civil society, and democratic action also found voice in the early twentieth century through Dewey's (1927 [1991]) exploration of "the public," social 


\section{Handbook on the politics of higher education}

life, and the potentials for effective democratic states: "The only statement which can be made is a purely formal one: the state is the organization of the public effected through officials for the protection of the interests shared by its members" (p. 33). Dewey also brought to the fore the role of education and information in the development of the public sphere and the evolution of the dynamic between the public and the state.

The existence of a state, however, does not determine the nature of that state. There are many forms and permutations of states, with states having more or less robust institutions and forms of governance emerging from contest between the states and their respective civil societies, and various other social, institutional, and political forces. At the same time, failed states, where no entity controls the legitimate use of force, or the rule of law and human rights no longer prevail, are unlikely to generate the conditions necessary for a functional civil society.

\section{EXPANDING THE SPHERES OF STATE CONTEST}

More contemporary scholarship of the state has worked to explain both the ways in which contest over state purposes is enacted, and how contest is generated beyond formal structures of the state and civil society. Scholars have noted the rise of institutionalist and structuralist approaches to understanding the political economy more broadly (Moe, 1984), which stand in contrast to behavioralist models of state action and the politics of state contest (Hay and Lister, 2006).

Critical scholars have also turned attention to the space between state and civil society, and to different approaches to understanding power and contest. Habermas's challenge to the nature of knowledge and the limitations of norms of law and democracy, along with his observations on essential contradictions in the modern welfare state and the potential for deliberative democracy in social change processes, reconceputalized essential norms of the civil society (Habermas, 1962; Ingram, 2010). His notion of a public sphere, juxtaposed with the state through civil society, offered a space for critique of the limitations of democratic action (Eley, 1992). Nancy Fraser (1992) suggested that inequalities in power limited the potential for Habermas's public sphere, a critique that applies more broadly to the civil society itself. Foucault's (1980) deconstruction of sovereignty, law, rights, domination, and power, which comprises a rejection of norms for understanding the state and civil society as deriving legitimacy from economic power, enabled reconsideration of earlier formulations of the state, the civil society, and the spaces in between. With particular salience for education, Freire (1985) delineated the relationship between the state, education, and inequities in power, as he pointed to those marginalized actors in society who lacked access to education, rights, and opportunities.

\section{THE CIVIL SOCIETY}

Jeffrey Alexander (2006) defined the initial understanding of civil society that emerged in the late seventeenth century as "a rather diffuse, umbrella-like concept referring to a plethora of institutions outside the state" (p. 24). These included economic markets, voluntary religious organizations, associations and organizations in both public and 
private spheres, and "virtually every form of cooperative and social relationship that created bonds of trust" (p. 24). The latter category encompassed political parties, legal institutions, as well as communicative bonds, public opinion, and moral and ethical norms. The creation and sustainability of such groups relied upon the voluntary nature of relations in the civil society, and freedom of association (Post and Rosenblum, 2002).

Alexander further argued that by the late nineteenth century the civil society was seen, particularly in Marxist models, as a sphere dominated by capitalist market relations and private gain. Over time, this concept was instantiated to such a degree that the market served as a proxy for the civil society in counterpoint to the state. This, in turn, led in subsequent neoliberal scholarship to a conceptual model of struggle between essentially two forces: the state and the market (Keane, 1988). The narrowed paradigm of hegemonic contest as a struggle between the state and the market also limited the conceptual terrain for understanding myriad other forms of conflict between public and private interests in society.

\section{THE EVOLUTION OF THEORIES OF THE CIVIL SOCIETY}

Cohen and Arato (1992) credited Hegel as the progenitor of modern conceptualizations of the civil society: "Indeed, no one could seriously contest Hegel's position as the most important nineteenth-century predecessor of and inspiration to twentieth-century analyses of civil society" (p. xiii). They attributed to Hegel the essential formulation of the elements of civil society under discussion to this day, "legality, privacy, plurality, association, publicity, and mediation" (p. xiv). Subsequently, theorists would add other considerations, particularly factors generally categorized as outside of the pluralist approach to the state and civil society, including shifting cultural and discursive understandings of the public sphere (Foucault, 1980; Habermas, 1962, 1987), global social movements (Gerbaudo, 2017), and the role of consciousness in challenging pluralist expressions of power (Lukes, 1974).

These concepts are usefully applied to the contemporary finance of public higher education in many national contexts, where the challenge of declining revenue for systems and institutions has largely been attributed to declining state support, and institutions have often responded by turning to the civil society and markets for new sources of revenue (Pusser, 2016; Slaughter and Rhoades, 2004; Weisbrod et al., 2008). A critical perspective would suggest that understanding the relationship between the state and public postsecondary institutions, as well as the construction of conceptual models of financial support, institutional legitimacy, and the appropriate institutional approaches to the civil society, are far more nuanced and complex than the state and market dichotomy that underpins much of the debate over contemporary postsecondary resource allocation.

Modern conceptualizations of the civil society stem from a classical liberal tradition that dates to Aristotle and the understanding of "the polis," the Greek city-state, and the role of the citizen in political society (Stone, 2012). Contemporary theory also draws upon Locke's concept of the civil society emerging from collective action to impose constraints on the state of nature, heightening individual and collective security, while at the same time preserving to the greatest degree possible the right to individual sovereignty, with a clear distinction between civil society and the institutions charged with implementing the 
will of those in the civil society. As Palmer (2002) put it, "Civil society is a kind of social order based on a particular kind of legal foundation" (p. 55). That legal foundation, which forms one basis for legitimate action by the state and individuals outside of the state, originates in civil society, and is maintained and renewed by institutions of the state and the civil society.

Scalet and Schmidtz (2002) presented the tension between society and government as the core question of liberalism. They suggested that resolution to that tension, from the standpoint of classical liberalism, entails limiting the state and its governance functions, while privileging the voluntary associations of civil society. In other interpretations of classical liberalism, the civil society gives legitimacy and authority to the state, and the definition of the civil society is, essentially, nearly everything that is not an apparatus of the state.

However, understanding the civil society as "not the state" is a little like providing the location of a country by stating where it is not found. Modern theorists have debated not only the conceptual location of the civil society, but also the conditions that define a successful civil sphere. Cohen and Arato (1992) pointed to three major analytical tensions over the civil society in contemporary scholarship: the tension between elite and participatory democracy; the contest between "rights oriented liberalism" and "communitarianism"; and the contest between the free market and the social welfare state (p. 3). Schumpeter (1942) identified elite democracy as a system that chose political leaders from the social and political elites, a system that was sustained by the power and approval of those elites. The model of participatory democracy, in contrast, holds that without meaningful and widely distributed participation by all citizens, democracy lacks legitimacy.

Constructions of the civil society also incorporate perspectives on rights-oriented liberalism and communitarianism. Classic liberalism suggests that legitimacy depends not on political participation, but on individual moral rights. It is those individual rights, rather than political actions, that shape a contest between individuals with moral rights and state efforts to adjudicate those rights. In the liberal formulation, states preserve legitimacy by privileging individual moral rights (Cohen and Arato, 1992). The communitarian position, on the other hand, challenges the idea of individuals as independent of social and historical associations. From the communitarian perspective, "The proper basis of moral theory is the community and its good, not the individual and her rights" (Cohen and Arato, 1992, p.9).

\section{THE STATE, CIVIL SOCIETY, AND RIGHTS}

Elements of the struggle between individual rights claims and the public good are also evident in the neoliberal effort to change the emphasis and influence of the state in favor of individual decision-making. This is problematic for understanding the roles of the state and civil society, on two levels: the notion of individual choices, and the aggregate of those choices driving competition that is so closely associated with the discourse and conceptualizations of libertarian and neoconservative approaches to the state have challenged long-standing understandings of the virtues of collective action through the civil society (Keane, 1988; Marginson, 1997), while the power of the market as a concept and social economic force has subsumed the broader role of civil society in political life 
(Harvey, 2005). As Alexander (2006) noted, “The identification of capitalism with civil society, in other words, is just one example of the reductive and circumscribing conflation of civil society with a particular kind of non-civil realm" (p. 35). These tensions point to the debate in the evolution of models of the civil society over the degree to which the civil society should be understood as essentially associational, depending upon civic institutions, or individualistic, based in the legitimacy of the rights of individuals. Palmer (2002) drew a line back to Hegel on this point, noting that Hegel conceptualized civil society as "the battleground where everyone's individual private interest meets everyone else's" (p. 56). That said, in contemporary political action we often see forms of civic contest, political action expressed through institutions, foundations, political parties, and formal structures, as well as formal and informal efforts by individuals and ad hoc groups. Both forms of action have been prominent and forceful as part of contest between the civil society and the state.

This locates market activities, as fundamentally private transactions, in the civil society (Alexander, 2006). However, as with many practices that originate in the civil society, markets exist with the direct and indirect support of the state and its institutions. The boundaries between state and civil society are permeable, and over time the degree to which each sphere shapes higher education shifts in light of contests over organization, governance, and policy. Over the past several decades, public universities that were for centuries chartered and subsidized by the state as nonprofit, non-market institutions for the public good are increasingly seen as market-driven institutions engaging in forprofit-like behaviors (Ehrenberg, 2000; Geiger, 2004). As the proportion of state financial support has declined, some institutional leaders have argued that the obligation of public institutions to the state is commensurately diminished. In the wake of the global economic crisis of the past decade, protests inspired by the Occupy movement have argued for a stronger state role in financing higher education, including lower tuition and debt relief (Gitlin, 2012). As the social, economic, and cultural currents in a given context shift, new contests and political formations with the state and beyond continue to shape the provision of postsecondary education (Valimaa, 2014).

\section{PUBLIC AND PRIVATE SPHERES}

Contemporary scholarship also addresses the degree to which the state and civil society are synonymous with "public" and "private" spheres of action. As a construct this is intuitively appealing, with the state understood as representing the polis, the political will of the whole, and deriving legitimacy from serving the public interest. The civil society can thus be understood, in contrast, as the realm of individual or associational transactions based upon private rights, an essentially private sphere. Both may be accurate in the abstract, while in practice each understanding gives the illusion of firmer boundaries than may be found: the state can be deeply shaped, in some instances captured, by interests in the civil society. At the same time, the civil society is shaped, and in some cases dominated, by state action. If the expectation is that the state fulfills demands from non-state entities and forces, including the civil society (the public), and that the civil society (the private) operates as a sphere independent of the state it seeks to influence, in many instances neither of those expectations are met. In practice, the state and civil society are at once 
independent, intertwined, and in contest, both embodying practices and structures shaped by public and private action. The association of state action as inherently public and civil society actions as private derives in part from interpretations of the work of Adam Smith (1776 [1979]), whose market logic has long influenced the characterization of public and private goods. In that paradigm, private goods can be seen as most efficiently created by individuals and associations in the civil society seeking individual interest and gain. It falls to the state to provide regulatory oversight and to produce those "public goods" that would not otherwise be produced, or could not be effectively produced, through private action (Marginson, 1997; Samuelson, 1954). The state also provides support for nonprofit, non-market organizations generating goods and opportunities that would not otherwise be produced through market activity, and for activities that, while not fully meeting the economic definition of public goods, fall into the realm of social welfare or the public interest (Weisbrod, 1998). Over the past half-century many states have faced the rise of demands for neoliberal policies, and challenges over the understandings of public and private goods, the public interest, and the degree to which the state has a role in the production of public goods and the public interest (Harvey, 2005). Demands for privatization, individual choice (Friedman and Friedman, 1980), and a "shrinking of the state" (Feigenbaum et al., 1999) have reinforced in political discourse the simple dualities of state and civil society, public and private, and state and market. Some of the primary terrains of contest over state and market, within the global political economy, are systems of education.

\section{BEYOND THE STATE AND CIVIL SOCIETY}

In the evolution of models of contest between the state and civil society relatively little attention has been paid to groups and individuals without formal legitimacy in those realms, actors at the margins of traditional norms of incorporation and status, social movements, and to contest that takes place outside of pluralist structures (Gerbaudo, 2017; Hannigan, 1985). Characterized by an initial lack of formalization, demands for social and political change, and their emergence outside of the traditional social and political institutions of society, social movements have been particularly influential in political contests over state purposes, including education, in various national contexts (Cook, 1996; Rojas, 2012). The mobilization by the "Dreamers," students and others marginalized by both state and civil society in the United States, as they seek to create greater access and legitimacy in higher education for undocumented individuals, has demonstrated that individuals and groups at the margins of formal sources of power nonetheless can shape political contest as cultural and symbolic forces that motivate political and social change (Nicholls, 2013).

\section{THE STATE, THE CIVIL SOCIETY, AND HIGHER EDUCATION}

To what degree can a model of contest between the state and civil society advance our understanding of the politics of higher education, the development and imposition of policies shaping colleges and universities, external and internal resource allocation, 
the organization and governance of postsecondary institutions and systems, and the exercise of power to achieve various ends? Answering this question requires an analysis of how the state and civil society have been most often treated in prior research and scholarship in higher education, with particular attention to the ways in which research in higher education has evolved by drawing relatively selectively from other disciplines, and from critical approaches to research. As Martinez-Aleman et al. (2015) argue, "Among Western theoretical frameworks critical theory has uniquely positioned scholars and researchers to explain and decode inequitable social relations and action in higher education" (p. 2). The following sections turn to the ways in which statetheoretical and critical perspectives offer particular insight into the politics of higher education.

\section{THE STATE AND HIGHER EDUCATION}

The introduction of state-theoretical approaches to education appeared earlier and more prominently in research on elementary and secondary schools than in postsecondary scholarship (Morrow and Torres, 1995). This occurred directly through the development of critical political theories of the role of the state in education (Carnoy and Levin, 1985; Freire, 1998; Giroux, 1983), and then indirectly through challenges to the scope and effectiveness of the state role in education (Chubb and Moe, 1990; Friedman and Friedman, 1980; Moe, 2011).

State missions and educational policies have been seen as key forces in state efforts to redress inequality (Carnoy, 1984; Mundy and Murphy, 2001), to produce public purposes and public goods that would otherwise not be produced through market mechanisms (Pusser, 2006; Marginson, 2007), and to create economic efficiency and social mobility (Labaree, 1997). However, the way in which the state is often presented in the research and scholarship of higher education suggests that the state and the government are one and the same. This represents a conflation of the concepts of the state and of the governance mechanisms within the state, and also leads to narrow analyses focused on government itself, rather than the more complex forces of the state that need to be understood. A number of scholars have identified the state on the basis of its stature as the foremost political authority, with government as a primary instrument for carrying out state goals. Hay and Lister (2006, p. 5) put it directly: "The modern state is, then, an institutional complex claiming sovereignty for itself as the supreme political authority within a defined territory for whose governance it is responsible." Robinson (2013, p. 556) pointed to the subordinate role of government this way: "The relationship between a government and its state is one of representation and authorized agency." Taylor (1985, p. 111) focused on both state delegation and duration as key factors in the distinction between state and government: "Governments are short-term mechanisms for administering long-term purposes of the state. Hence every state is served by a continuous succession of governments. But governments only represent the state, they cannot replace it." Thus, understanding the state is a distinct conceptual challenge from understanding government.

There are notable exceptions in the scholarship of higher education in the United States, where the institutions of government have been seen as mechanisms of the state, not as the state itself (Barrow, 1990; Clark, 1983; Hardy, 1990; Slaughter, 1990). And it is also the 


\section{Handbook on the politics of higher education}

case that research on the politics and policies shaping the postsecondary arena do treat colleges and universities as subject to forces that include the government, the legal system, the political institutions of the national context, and market forces. Yet, only rarely has attention been turned to the integration of each of these factors in conceptual models centered on the state and the civil society. This is hardly unique to academic scholarship. In the United States there is relatively little public conversation or consideration of the role of "the state" in contemporary life: the fundamental unit of analysis in discussions of politics and policies is "the government," which seems to stand for the virtues or faults of the myriad institutions, forces, and interactions that, taken together, characterize state action. The neoliberal policies that have become increasingly central to political action shaping higher education, in the United States and globally over the past five decades, are driven by a contrast between private sector activity, particularly through markets, and the actions of government, rather than the wider constellation of forces shaping the contemporary state and its policies. The conceptual construct of a monolithic private sector or government misses the logics of power that bind together the efforts of the range of forces that shape state ideology, action, and legitimacy (Ordorika and Lloyd, 2015). At the same time, allowing "government" to stand for "the state" analytically misses the opportunity to utilize a more nuanced analytical approach to political action, and to illuminate the multifaceted imaginaries and discourses that drive contest and bring new formations into being (Lukes, 1974; Pusser, 2015).

Seeking to keep the state and government analytically distinct does not suggest that governments necessarily implement purposes different from those reflected in the missions and goals of the state. The degree of consonance between state and government, and the interests of government actors and institutions, varies by state, national context, and historical moment. However, when government, rather than the state, becomes the unit of analysis, critique, and contest, a broader conversation about national purpose as reflected in the complexity of state action, and the effort to realize collective goals through the myriad facets of state action, may be neglected. As one example, the neoliberal challenge to the role of the social welfare state and the public provision of state services, in the United States and globally (Harvey, 2005; Krugman, 2013), rather than being a contest over the goals of the state as evidenced by the allocation of resources, the protection of legal and human rights, the creation of public goods and public purposes through state institutions, is presented in much debate within political society as simply a question of the appropriate size and reach of government. That challenge has been accompanied by the valorization of the private sector and the market, coupled with a characterization of the government as inefficient, resistant to innovation, and protective of entrenched interests (Friedman and Friedman, 1980; Moe, 2011).

In seeking to understand the contemporary role of the state in higher education, it is useful to return to a central premise: in many nations public universities are created, chartered, financed, and governed by state action. While private universities emerge from the civil society, in many cases they too are chartered by the state, and in the United States they are to some degree regulated and financed by the state through state-subsidized student grants and loans, research grants, and tax policy (Mettler, 2014). Policies that significantly shape the activities of public and private universities in the United States, such as Title IV of the Higher Education Act and Title IX of the Educational Amendments Act, were created through contest between the state and civil 
society, and continue to be challenged through political action (Gladieux and Wolanin, 1976; Pusser, 2016).

Since the organization and functions of state institutions in the United States and many other countries are most directly shaped by formal and informal political decision-making, in those nations they can also be considered political institutions of the state. This is an essential condition for understanding public universities, and a condition with considerable influence over the policies and practices of private postsecondary institutions as well. Building on Gramsci (1971), scholars have argued that colleges and universities, as political institutions of the state, are both sites of contest over state authority and legitimacy, and also instruments in broader contests for control of the state. That is, individuals and groups outside of the state often locate protests and other forms of political action on sites with particular historical and symbolic salience in national contests. Prominent among those sites are colleges and universities (Ordorika and Lloyd, 2015; Pusser and Marginson, 2013; Valimaa, 2014). State institutions also serve as important instruments in broader political contests, such as efforts to privatize state functions, policies on unionization, affirmative action, immigration, and more. Such contests often make highly visible the continual tension between the state, the civil society, market interests, and actors operating outside the formal structures of contest (Pusser, 2015). Ordorika and Lloyd (2015) present several necessary conditions for creating a political theory of governance in higher education, with particular attention to history and context:

Framing political contest in education as a confrontation over ideology and resource allocation; enabling the understanding of decision-making structures and processes in education as a historical product of power struggles between dominant and subaltern groups in education and the broader state; explaining the dynamics of educational reform as a consequence of competing demands for the reproduction and production of ideology and skills on the one hand and struggles for social transformation and equality on the other; and establishing the linkages between political contest at the internal and external levels as central to understanding new sites of educational contest and reform. (Ordorika and Lloyd, 2015, p. 145)

\section{THE CIVIL SOCIETY AND HIGHER EDUCATION}

Analysis of the contest over the organization and governance of a political institution of the state necessarily draws upon the role of the civil society in shaping and contesting state action (Pusser, 2015). Literature on the institutions of civil society and higher education in the United States has addressed such arenas of contest as law and higher education (Garces, 2013; Olivas, 2008; Rooksby, 2016), legislative policy (Doyle, 2012; Gladieux and Wolanin, 1976), market organizations and economic policy shaping higher education (Ehrenberg, 2000; Weisbrod et al., 2008), unions in postsecondary education (Rhoades, 1998; Nocera and Strauss, 2016), and social movements shaping student access and success (Nicholls, 2013; Rojas, 2012). Considerable research has also addressed civic engagement, the efforts of community-based organizations and non-governmental organizations in collaboration with colleges and universities (Ehrlich, 2000). However, the civil society is less often treated as a unit of theoretical analysis in its own right.

In the United States, the concept of the civil society has long been strongly entwined 
with understandings of citizenship and, in turn, the right to participate in political society (Stone, 2012). As Seligman (1992) stated:

In the eighteenth and nineteenth centuries, civil society came to imply a form of universal citizenship within the nation-state, based on the one hand on the principles of individualism and on the other on the participation of these individuals in public life, a participation that was in turn based on the mutuality of citizens in the form of compacts, contracts, and the moral, economic, social and political ties binding these individuals. (Seligman, 1992, p. 111)

Along with citizenship and participation, the concept of democratic equality has been a central concern in the civil society, one that significantly shapes the contest over the organization and practices of state institutions, with particular salience for higher education (Labaree, 1997). Social, cultural, and political challenges based on membership, freedom of individual and collective agency, and equality of opportunity have long motivated action emerging from the civil society in the United States. The organization of the state, with institutions devoted to protecting individual rights, social welfare, and equality reflects those broader goals. At the same time, the divergent interests within the nation and the collective failure to fully realize these fundamental goals have been the driver of persistent social and political contest, and generated social movements seeking to transform society and state. The contest over national goals for higher education, and over the state role in realizing those goals, is reflected in conflict over the organization and governance of colleges and universities. While the relationship between the state and civil society and postsecondary institutions varies widely in different national contexts, the essential conceptual model pertains. David Labaree (1997) articulated three fundamental goals for education in the United States: democratic equality, social efficiency, and social mobility. Each of the goals has powerful adherents. Yet the three are also conceptually and practically in conflict. As Labaree (1997) noted, "The terms of this choice arise from a fundamental source of strain at the core of any liberal democratic society, the tension between democratic politics (public rights) and capitalist markets (private rights), between majority control and individual liberty, between political equality and social inequality" (p. 41). These essential conflicts of vision and purpose ensure that contest is a constant, as the state reflects the multiple and contradictory goals, and the concurrent tensions between the state and interests within and beyond civil society.

As with scholarly analyses of the state and higher education, discrete elements of the civil society are central to discussions of the politics of higher education but rarely linked in comprehensive analysis. In part this may be due to the dominion of market models for understanding higher education. The market not only draws attention away from the broader civil society and other analytical frames, but in much of the contemporary research and commentary on higher education policy the market is treated as a force dominating nearly all other aspects of civil society in shaping higher education (Kirp, 2003; Weisbrod et al., 2008). From a state-theoretical perspective, markets certainly matter, but it is the nexus of the range of institutions and cultural and social dynamics outside of the state that constitute the civil society, which in contest with the state shape the conditions for market activity. In the United States, in contests over postsecondary policies at the state, regional, or federal level, the list of actors and actions and interactions in the civil society that shape the debate includes political parties, nonprofit economic advocacy groups, religious organizations, nonprofit legal centers, consortia 
of states and cities, for-profit commercial enterprises and corporations, organizations devoted to single-issue advocacy, nonprofit groups representing specific populations in the broader society, consortia of public or private higher education institutions, unions, faculty, and staff organizations. There are also organizations devoted to specific student populations within higher education institutions, human rights organizations, and environmental groups. The list, if not endless, is endlessly complex. Scholars must also reckon with the role of information and discourse, the nature of the public sphere in a particular state, reputation, prestige and positional goods, cultural and historical norms of organization and action, the power of the private sector, the great personal and corporate wealth directed at influencing state action, and the role of media in shaping norms and understandings of debate.

As Harvey (2005) has noted, to understand the rise of policies shaping the form and practices of states, one also needs to consider the "construction of consent," a process by which power and resources are devoted to legitimizing new forms of state action: "Powerful ideological influences circulated through the corporations, the media, and the numerous institutions that constitute the civil society - such as the universities, schools, churches and professional associations" (p. 40). In contemporary scholarship, such nuanced understanding has only recently been applied to understanding the effort to gain and sustain influence by particular interests in higher education (Pusser and Marginson, 2013; Slaughter and Leslie, 1997).

\section{THE ROLE OF HIGHER EDUCATION INSTITUTIONS}

As with the study of the civil society and higher education, research and scholarship that address the political role of higher education institutions from a state-theoretical perspective are a relatively recent development. Over the past few decades a number of works have looked at the role of public schools, unions, interest groups, and cultural shifts in shaping political contests over the organization and governance of elementary and secondary education in the United States (Apple, 1982; Henig, 1995). The scholarship of the politics and policy of higher education has generally treated the university as an organization that is "acted upon," in the political arena, rather than as an actor with political interests and political salience in its own right. In the United States this stemmed in part from normative expectations of the university's obligations under the codified autonomy granted many public universities, in an effort to protect them from political interference. In exchange, public universities have been understood to be nonpartisan actors. In many cases public universities are legally bound to avoid partisan political action, an approach that seeks to preserve legitimacy with all elements of political society.

This apolitical stance has proven to be difficult to sustain in practice. Public and private universities have been active in a number of realms in which they see a need to protect the rights and well-being of the institutions and their constituencies, what one might categorize as mission-driven politics. A few examples would include efforts to redress racial and gender inequality in admissions and other institutional functions (Chang et al., 2003; Garces, 2013), to preserve access for undocumented students (Nicholls, 2013), and to contest the organization of student unions (Nocera and Strauss, 2016). While the political goals and strategies of colleges and universities vary widely, it is important to note that 


\section{Handbook on the politics of higher education}

many, if not all universities, in various state contexts, will eventually find themselves as sites, instruments, or actors in political contest over mission-driven activities.

Contemporary universities are also often enmeshed in political action over revenuedriven activities. Examples include bargaining with legislatures over the setting of tuition and fees; establishing the degree to which universities can capitalize on research through patenting and licensing (Rooksby, 2016); and through constructing alliances with for-profit enterprises more generally, the shift to what Slaughter and Leslie (1997) termed "academic capitalism." Here universities in the United States have been at times reactive, as with responses to Congressional changes in patenting policy under the Bayh-Dole Act; and at other times proactive, in shifting resources, curriculum, and labor force policies in order to maximize revenue through economic partnerships (Weisbrod et al., 2008). This has also had the effect of furthering the legitimacy of higher education as a process of human capital investment, rather than as a collective public good. This is a shift with significant implications for the broader contest over the role of education within a neoliberal state (Slaughter et al., 2015). What this suggests is that in developing state-centered models of political action in higher education, universities can be seen as sites, instruments, and actors in broader political contest.

\section{SOCIAL MOVEMENTS AND HIGHER EDUCATION}

One of the challenges in state-theoretical studies of political institutions, including universities, is that the model has generally been applied to pluralist contests, and to formal organizations: labor unions, state institutions, religious organizations, military and police forces, political interest groups, and parties. Yet, in many instances, change is driven by social movements that are informal, relying on the mobilization of ideas, alliances, ideologies, and beliefs that may or may not coalesce into formal institutions (Gitlin, 2012; Nicholls, 2013). Such social movements both generate new visions and push the process of implementation forward (Hannigan, 1985). In some instances, creating formal declarations or structures may place the actors involved in a movement at risk from the state or elements of the civil society, as in the case of undocumented students involved in political action on campuses (Nicholls, 2013). Despite that vulnerability, in various national contexts social movements have been powerful forces in shaping the structure and processes of the state and the beliefs and actions of the civil society (Rhoads and Mina, 2001).

The use of theories of social movements also has particular salience for higher education. As sites of critical inquiry, and as symbols of national purposes, universities have often been central in mobilizations of formal and informal groups seeking to draw attention to demands for change and to pressure the state or civil society to take action. Rojas (2012) stated, "Social movements go hand in hand with universities" (p. 256); and Ordorika and Lloyd (2015) referenced a long history of conflicts over universities between authorities and elements of the civil society in different national contexts. 


\section{POWER AND CRITICAL STANDPOINTS}

The concept of power is also a central concern of state-theoretical approaches to understanding political contest. In the United States, power as a theoretical construct has not factored significantly in the literature on the politics of higher education. In work on postsecondary policy and governance, power has been traditionally invoked indirectly, in research on the relative strength of formal interest groups, legislative formations, executive branches, or as part of pluralist models of decision-making (Baldridge, 1971; Doyle, 2012; Gladieux and Wolanin, 1976). In the contest between the state and civil society over postsecondary education, power is manifested both in struggles for hegemony, and in the exercise of state authority over postsecondary policy. In civil society, economic power is often brought to bear on postsecondary politics, as when for-profit corporations make contributions to political representatives, or when interest groups seek to reduce taxes that fund state institutions.

Postsecondary institutional power also shapes politics and policy in myriad other ways, as when private colleges bring litigation to protect mission values, or universities host political leaders on campuses. Again, there is often no consensus within the civil society on postsecondary policy. Private universities and public universities may have different interests and sources of legitimacy in particular contests. Some nonprofit organizations provide political and economic support for increased privatization, others for a more effective production of public goods through education. This again points to the concept of the civil society as a too-broad instrument for analysis. It is the relations of power and the terrain of contest within the civil society and between civil society and the state that are central to greater understanding of the politics of higher education.

The power exerted by the state itself in postsecondary education can be based on a variety of sources of legitimacy, or relatively monolithic structures and practices. That is, depending on the state itself, the provision of higher education may reflect something of a consensus of the civil society and other factors shaping state action, the sum of the forces that comprise the state. Consensus itself also needs to be evaluated for the differences in power and access of various actors in political society, adherence to social justice, equity, open discourse, and inclusion that underpin the legitimacy of consensus (Lukes, 1974).

It is also the case that a relatively narrow set of powerful actors and practices can shape the structure of higher education by imposing its will on the broader society. This was the case in Chile, in the aftermath of a military coup in 1973. Over the next 16 years, the regime led by General Augusto Pinochet introduced rigid neoliberal economic policies that continued to sharply influence the policies and politics of the Chilean state and its restructured higher education system long after the return of civilian rule (Oppenheim, 2007). The study of the exercise of power upon and through higher education turns attention to a complex and historically mediated terrain, one that is inevitably linked to the understanding of broader contests over the state and society.

\section{FROM THEORY TO PRACTICE}

Conceptual models addressing the ways in which the state and civil society in contest shape higher education have been largely absent from research and scholarship for much 
of the history of the field. While more frequently invoking state and civil society in postsecondary research would add greater understanding, deconstructing the elements of each sphere, recognizing the importance of actors and organizations outside of those conceptual frames, and focusing on power and critical standpoints will open additional avenues to comprehension of the nature of postsecondary education.

A state-theoretical approach makes available broader perspectives on the politics and policies, organization and governance, and historical contexts of higher education. The first question that must be asked about the state and higher education in any given national context is, "What is the mission of higher education within this state project, and what role do various elements of the state play in meeting that mission?" Surprisingly, it is a question that is often neglected in contemporary research, where instantiated norms of mission and legitimacy crowd out more nuanced approaches to the role of the state and contest in postsecondary education.

As one contemporary example, debates in the United States over the rising level of tuition and fees in public higher education over the past two decades are generally framed as contests between state legislatures and public universities (Ehrenberg, 2000). Universities have used declines in direct state funding to justify requests for tuition increases. Legislatures have challenged universities for excessive spending, inefficiency, and a lack of accountability. Many scholars and policy analysts have tended to accept both arguments as inevitable, directly or indirectly acknowledging the power of the legislature, even where the universities have significant degrees of codified autonomy, and despite tuition dynamics varying widely globally, and where the empirical evidence of inefficiency or poor accountability is unclear. Scholars using a critical approach have noted persistent challenges to the legitimacy of fee increases, pointing to historical and contemporary contests over the financing of higher education (Misiaszek et al., 2012; Pusser, 2016). The need for deconstruction of traditional norms for understanding power and politics in higher education is manifest in the debate over rising tuition, which calls for analyses of the many social and economic forces contending for control of the political economy of college access. It also understates a key transformation taking place in the financing of public higher education globally, a shift from broad public financial support of universities through taxation and public expenditure to a privatized system of financing through individual tuition, and tax policies that offer subsidies that disproportionately favor wealthier families and students (Mettler, 2014).

Given contemporary demands in a wide array of national contexts for the transformation of universities and systems of higher education, a state-theoretical approach becomes critically important for postsecondary research and scholarship. Understanding higher education as shaped by the contest between the state, the civil society, and forces outside of those spheres opens further possibilities for a more complete and illuminating understanding of the politics of higher education.

\section{REFERENCES}

Alexander, J.C. (2006). The Civil Sphere. New York: Oxford University Press. Apple, M. (1982). Education and Power. Boston, MA: Routledge \& Kegan Paul. 
Baldridge, J.V. (1971). Power and Conflict in the University: Research in the Sociology of Complex Organizations. New York: J. Wiley.

Barrow, C.W. (1990). Universities and the Capitalist State: Corporate Liberalism and the Reconstruction of American Higher Education, 1894-1928. Madison, WI: University of Wisconsin Press.

Berdahl, R. (1971). Statewide Coordination in Higher Education. Washington, DC: ACE.

Berdahl, R. (1990). Academic freedom, autonomy and accountability in British universities. Studies in Higher Education, 15(2), 169-181.

Carnoy, M. (1984). The State and Political Theory. Princeton, NJ: Princeton University Press.

Carnoy, M. and Levin, H.M. (1985). Schooling and Work in the Democratic State. Stanford, CA: Stanford University Press.

Chandhoke, N. (1995). State and Civil Society: Explorations in Political Theory. New Delhi: SAGE Publication India.

Chang, M.J., Witt, D., Jones, J., and Hakuta, K. (eds) (2003). Compelling Interest: Examining the Evidence on Racial Dynamics in Colleges and Universities. Stanford, CA: Stanford University Press.

Chubb, J.E. and Moe, T.M. (1990). Politics, Markets and America's Schools. Washington, DC: Brookings Institution.

Clark, B.R. (1983). The Higher Education System: Academic Organization in Cross-National Perspective. Berkeley, CA: University of California Press.

Cohen, J.L. and Arato, A. (1992). Civil Society and Political Theory. Cambridge, MA: MIT Press.

Cook, M.L. (1996). Organizing Dissent: Unions, the State, and the Democratic Teachers' Movement in Mexico. University Park, PA: Pennsylvania State University Press.

Dewey, J. (1927 [1991]). The Public and Its Problems. Athens, OH: Swallow Press.

Doyle, W.R. (2012). The politics of public college tuition and state financial aid. Journal of Higher Education, $83(5), 617-647$.

Ehrenberg, R.G. (2000). Tuition Rising: Why College Costs So Much. Cambridge, MA: Harvard University Press.

Ehrlich, T. (ed.) (2000). Civic Responsibility and Higher Education. Phoenix, AZ: Oryx Press.

Eley, G. (1992). Nations, publics, and political cultures: placing Habermas in the nineteenth century. In C. Calhoun (ed.), Habermas and the Public Sphere (pp. 289-339). Cambridge, MA: MIT Press.

Feigenbaum, H., Henig, J., and Hamnett, C. (1999). Shrinking the State: The Political Underpinnings of Privatization. Cambridge: Cambridge University Press.

Foucault, M. (1980). Power/Knowledge. Brighton: Harvester Press.

Fraser, N. (1992). Rethinking the public sphere: a contribution to the critique of actually existing democracy. In C. Calhoun (ed.), Habermas and the Public Sphere (pp. 109-142). Cambridge, MA: MIT Press.

Freire, P. (1985). The Politics of Education. South Hadley, MA: Bergin \& Garvey.

Freire, P. (1998). Politics and Education. Los Angeles, CA: UCLA Latin American Center Publications.

Friedman, M. and Friedman, R. (1980). Free to Choose: A Personal Statement. New York: Harcourt Brace Jovanovich.

Garces, L.M. (2013). Understanding the impact of affirmative action bans in different fields of graduate studies. American Educational Research Journal, 50(2), 251-284.

Geiger, R.L. (2004). Knowledge and Money: Research Universities and the Paradox of the Marketplace. Stanford, CA: Stanford University Press.

Gerbaudo, P. (2017). The Mask and the Flag: Populism, Citizenism and Global Protest. London: Hurst \& Company.

Giroux, H.A. (1983). Critical Theory and Educational Practice. Victoria: Deakin University Press.

Gitlin, T. (2012). Occupy Nation: The Roots, the Spirit, and the Promise of Occupy Wall Street. New York: Harper Collins.

Gladieux, L.E. and Wolanin, T.R. (1976). Congress and the Colleges: The National Politics of Higher Education. Lexington, MA: Lexington Press.

Gramsci, A. (1971). Selections from Prison Notebooks. New York: International Publishers.

Habermas, J. (1962). The Structural Transformation of the Public Sphere. Cambridge, MA: MIT Press.

Habermas, J. (1987). The Theory of Communicative Action (Vol. 2). Lifeworld and System: A Critique of Functionalist Reason. Boston, MA: Beacon Press.

Hannigan, J.A. (1985). Alain Touraine, Manuel Castells and social movement theory: a critical appraisal. Sociological Quarterly, 26(4), 435-454.

Hardy, C.P. (1990). Putting power into university governance. In J.C. Smart (ed.), Higher Education Handbook of Theory and Research, Vol. VI (pp. 393-426). New York: Agathon Press.

Harvey, D. (2005). A Brief History of Neoliberalism. London: Oxford Press.

Hay, C. and Lister, M. (2006). Introduction: theories of the state. In C. Hay, M. Lister, and D. Marsh (eds), The State: Theories and Issues (pp. 1-20). New York: Palgrave Macmillan.

Henig, J.R. (1995). Rethinking School Choice: Limits of the Market Metaphor. Princeton, NJ: Princeton University Press. 


\section{Handbook on the politics of higher education}

Ingram, D. (2010). Habermas: Introduction and Analysis. Ithaca, NY: Cornell University Press.

Keane, J. (1988). Democracy and Civil Society. London: Verso.

Kerr, C. (1963). The Uses of the University. Cambridge, MA: Harvard University Press.

Kirp, D.L. (2003). Shakespeare, Einstein and the Bottom Line. Cambridge, MA: Harvard University Press.

Krugman, P. (2013). End this Depression Now! New York: W.W. Norton.

Labaree, D.F. (1997). Public goods, private goods: the American struggle over educational goals. American Educational Research Journal, 34, 39-81.

Lukes, S. (1974). Power: A Radical View. London: Macmillan.

Mann, M. (1988). States, War and Capitalism: Studies in Political Sociology. Oxford: Basil Blackwell.

Marginson, S. (1997). Markets in Education. Melbourne: Allen \& Unwin.

Marginson, S. (2007). The public/private division in higher education: a global revision. Higher Education, 53, 307-333.

Martinez-Aleman, A.M., Pusser, B., and Bensimon, E.M. (2015). Introduction. In A.M. Martinez-Aleman, B. Pusser, and E.M. Bensimon (eds), Critical Approaches to the Study of Higher Education (pp. 1-6). Baltimore, MD: Johns Hopkins University Press.

Mettler, S. (2014). Degrees of Inequality: How the Politics of Higher Education Sabotaged the American Dream. New York: Basic Books.

Misiaszek, G.W., Jones, L.I., and Torres, C.A. (2012). Selling out academia? Higher education, economic crises, and Freire's generative themes. In B. Pusser, K. Kempner, S. Marginson, and I. Ordorika (eds), Universities and the Public Sphere: Knowledge Creation and State Building in the Era of Globalization (pp. 179-196). New York: Routledge.

Moe, T.M. (1984). The new economics of organization. American Journal of Political Science, 28(4), 739-777.

Moe, T.M. (2011). Special Interest: Teachers Unions and America's Public Schools. Washington, DC: Brookings Institution Press.

Morrow, R.A. and Torres, C.A. (1995). Social Theory and Education, a Critique of Theories of Social and Cultural Reproduction. Albany, NY: State University of New York Press.

Mundy, K. and Murphy, L. (2001). Transnational advocacy, global civil society? Emerging evidence from the field of education. Comparative Education Review, 45(1), 85-126.

Nicholls, W.J. (2013). The DREAMers: How the Undocumented Youth Movement Transformed the Immigrant Rights Debate. Stanford, CA: Stanford University Press.

Nocera, J. and Strauss, B. (2016). Indentured: The Inside Story of the Rebellion against the NCAA. New York: Portfolio/Penguin.

Olivas, M.A. (2008). The political economy of the DREAM ACT and the legislative process: a case study of comprehensive immigration reform. Wayne Law Review, 55, 1757-1810.

Oppenheim, L.H. (2007). Politics in Chile: Socialism, Authoritarianism, and Market Democracy, 3rd edn. Boulder, CO: Westview Press.

Ordorika, I. and Lloyd, M. (2015). The state and contest in the globalized era: critical perspectives. In A.M. Martínez Alemán, B. Pusser, and E.M. Bensimon (eds), Critical Approaches to the Study of Higher Education (pp. 130-152). Baltimore, MD: Johns Hopkins University Press.

Palmer, T.G. (2002). Classical liberalism and civil society: definitions, history and relations. In N.L. Rosenblum and R.C. Post (eds), Civil Society and Government (pp. 48-78). Princeton, NJ: Princeton University Press.

Post, R.C. and Rosenblum, N.L. (2002). Introduction. In N.L. Rosenblum and R.C. Post (eds), Civil Society and Government (pp. 1-25). Princeton, NJ: Princeton University Press.

Pusser, B. (2004). Burning Down the House: Politics, Governance and Affirmative Action at the University of California. Albany, NY: State University of New York Press.

Pusser, B. (2006). Reconsidering higher education and the public good: the role of public spheres. In W. Tierney (ed.), Governance and the Public Good (pp. 11-28). Albany, NY: State University of New York Press.

Pusser, B. (2015). A critical approach to power in higher education. In A.M. Martinez-Aleman, B. Pusser, and E.M. Bensimon (eds), Critical Approaches to the Study of Higher Education (pp. 59-79). Baltimore, MD: Johns Hopkins University Press.

Pusser, B. (2016). A state theoretical approach to understanding contest in higher education. In S. Slaughter and B. Taylor (eds), Higher Education, Stratification, and Workforce Development: Competitive Advantage in Europe, the US and Canada (pp. 331-348). Dordrecht: Springer International Publishing.

Pusser, B., Kempner, K., Marginson, S., and Ordorika, I. (2012). Introduction. In B. Pusser, K. Kempner, S. Marginson, and I. Ordorika (eds), Universities and the Public Sphere: Knowledge Creation and State Building in the Era of Globalization (pp. 1-6). New York: Routledge.

Pusser, B. and Marginson, S. (2012). The elephant in the room: power, politics and global rankings. In M. Bastedo (ed.), Organizing Higher Education (pp. 86-117). Baltimore, MD: Johns Hopkins University Press.

Pusser, B. and Marginson, S. (2013). University rankings in critical perspective. Journal of Higher Education, 84(4), 544-568.

Rhoades, G. (1992). Beyond "the state": Interorganizational relations and state apparatus in postsecondary 
education. In J.C. Smart (ed.), Higher Education: Handbook of Theory and Research (pp. 84-192). New York, NY: Agathon Press.

Rhoades, G. (1998). Managed Professionals: Unionized Faculty and Restructuring Academic Labor. Albany, NY: State University of New York Press.

Rhoads, R.A. and Mina, L. (2001). The student strike at the National Autonomous University of Mexico: a political analysis. Review of Higher Education, 45(3), 334-353.

Robinson, E.H. (2013). The distinction between state and government. Geography Compass, 7/8, 556-566.

Rojas, F. (2012) Social movements in the university. In M. Bastedo (ed.), Organizing Higher Education (pp. 256-276). Baltimore, MD: Johns Hopkins University Press.

Rooksby, J.H. (2016). The Branding of the American Mind: How Universities Capture, Manage, and Monetize Intellectual Property and Why It Matters. Baltimore, MD: Johns Hopkins University Press.

Samuelson, P. (1954). The pure theory of public expenditure. Review of Economics and Statistics, 36(4), $387-389$.

Scalet, S. and Schmidtz, D. (2002). State, civil society and classical liberalism. In N.L. Rosenblum and R.C. Post (eds), Civil Society and Government (pp. 26-47). Princeton, NJ: Princeton University Press.

Schumpeter, J.A. (1942). Capitalism, Socialism and Democracy. London: Taylor \& Francis Books.

Seligman, A.B. (1992). The Idea of Civil Society. New York: Free Press.

Simon, R. (1982). Gramsci's Political Thought: An Introduction. London: Lawrence \& Wishart.

Slaughter, S. (1990). The Higher Learning and High Technology: Dynamics of Higher Education Policy Formation. Albany, NY: SUNY Press.

Slaughter, S. and Leslie, L.L. (1997). Academic Capitalism. Baltimore, MD: Johns Hopkins University Press.

Slaughter, S. and Rhoades, G. (2004). Academic Capitalism and the New Economy. Baltimore, MD: Johns Hopkins University Press.

Slaughter, S., Taylor, B.J., and Rosinger, K.O. (2015). A critical reframing of human capital theory in US higher education. In A.M. Martinez-Aleman, B. Pusser, and E.M. Bensimon (eds), Critical Approaches to the Study of Higher Education (pp. 80-102). Baltimore, MD: Johns Hopkins University Press.

Smith, A. (1776 [1979]), An Inquiry into the Wealth of Nations. Harmondsworth: Penguin.

Stone, D. (2012). Policy Paradox: The Art of Political Decision Making, 3rd edn. New York: W.W. Norton.

Taylor, P.J. (1985). Political Geography: World-Economy, Nation-State, and Locality. London: Longman Group.

Trow, M. (1976). Elite higher education: an endangered species?, Minerva, 14(3), 355-376.

Valimaa, J. (2014). University revolutions and academic capitalism: a historical perspective. In B. Cantwell and I. Kauppinen (eds), Academic Capitalism in the Age of Globalization (pp. 33-54). Baltimore, MD: Johns Hopkins University Press.

Weber, M. (1947). The Theory of Social and Economic Organization. Glencoe, IL: Free Press.

Weisbrod, B.A. (1998). The nonprofit mission and its financing: growing links between nonprofits and the rest of the economy. In B.A. Weisbrod (ed.), To Profit or Not To Profit: The Commercial Transformation of the Nonprofit Sector (pp. 1-21). Cambridge: Cambridge University Press.

Weisbrod, B.A., Ballou, J.P., and Asch, E.D. (2008). Mission and Money: Understanding the University. Cambridge: Cambridge University Press. 